\title{
Growth physiology of Brassica rapa var. yellow sarson under integrated nutrient management and seed soaking approaches in eastern sub-Himalayan plains
}

\author{
Saikat Mookherjee*, Ganesh Chandra Malik ${ }^{1}$, Subhendu Bandyopadhyay and Biplab Mitra \\ Uttar Banga Krishi Viswavidyalaya, Pundibari, Cooch Behar -736165 (West Bengal), INDIA \\ ${ }^{1}$ Palli Siksha Bhavana, Institute of Agriculture, Visva-Bharati, Sriniketan-731236 (West Bengal), INDIA \\ *Corresponding author. E-mail: s.mookherjee@live.com
}

Received: May 28, 2014; Revised received: August 25, 2014; Accepted: October 02, 2014

\begin{abstract}
The field experiment was conducted at Uttar Banga Krishi Viswavidyalaya, West Bengal, India during rabi 2007-08 to 2008-09 to study the growth and productivity of yellow sarson under different nutrient management practices and pre-sowing seed soaking. The highest value of LAI (4.00), apart from the maximum plant height $(129.97 \mathrm{~cm})$, dry matter accumulation $\left(481.93 \mathrm{~g} \mathrm{~m}^{-2}\right)$ at 90 days, crop growth rate $\left(12.29 \mathrm{~g} \mathrm{~m}^{-2}\right.$ day $\left.^{-1}\right)$ in between 45 to 60 days, root dry weight $\left(1.645 \mathrm{~g} \mathrm{plant}^{-1}\right)$ with the highest average root diameter $(0.932 \mathrm{~mm})$ were observed in treatments receiving $75 \%$ recommended dose of chemical fertilizer with farm yard manure, Azotobacter and phosphate solubilizing bacteria as non-chemical source. Similarly at 45 days of crop age, significantly higher stomatal conductance $\left(701.68 \mathrm{~m} \mathrm{~mol} \mathrm{~m}^{-2} \mathrm{~s}^{-1}\right)$ and transpiration rate $\left(4.55 \mathrm{~m} \mathrm{~mol} \mathrm{~m}^{-2} \mathrm{~s}^{-1}\right)$ were reflected by the same treatment combination. These were attributed to the production of maximum seed yield $\left(1374 \mathrm{~kg} \mathrm{ha}^{-1}\right)$, which was $39.91 \%$ higher than the recommended dose of chemical fertilizer application. On an average, seeds soaked with water before sowing reflected $9 \%$ lesser yield $\left(1103 \mathrm{~kg} \mathrm{ha}^{-1}\right)$ against chemical soaking. Yellow sarson crop grown with integrated nutrient management practice consisting $75 \%$ of the recommended dose of chemical fertilizer along with farm yard manure $\left(5 \mathrm{t} \mathrm{ha}^{-1}\right)$, Azotobacter $\left(5 \mathrm{~kg} \mathrm{ha}^{-1}\right)$ and phosphate solubilizing bacteria $\left(5 \mathrm{~kg} \mathrm{ha}^{-1}\right)$ coupled with seed soaking in $100 \mathrm{ppm} \mathrm{KH}_{2} \mathrm{PO}_{4}$ confirms to be the best treatment combination from the treatment schedule considered during the study for the sub-Himalayan plains of West Bengal, India in terms of crop growth and productivity.
\end{abstract}

Keywords: Growth attributes, Nutrient uptake, Root growth, Seed yield, Yellow sarson

\section{INTRODUCTION}

Rapeseed-mustard group of crops is among the oldest cultivated plants in human civilization .It was cultivated by ancient civilization in Asia and Mediterranean. Its use has been recorded as early as 2000BC in India (Colton and Potter, 1999). It is a group of oilseed crops which assumes the significance in Indian national economy by occupying the second position next to groundnut and is considered as a 'cash crop'. Biologically, the rapeseed and mustard plants belongs to the family Crucifarae and under the genus Brassica with large number of species and sub species cultivated in India. Rapeseed-mustard (Brassica spp.) is the third important oilseed crop in the world after soybean (Glycine max) and palm (Elaeis guineensis) (Shekhawat et al., 2012). Among the seven edible oilseeds cultivated in India, rapeseed-mustard contributes $28.6 \%$ in the total production of oilseed. This energy rich crop plays an important role in human nutrition and animal feed, occupying a key position in the diet of Indian masses. Rapeseed-mustard (Brassica spp.) is a common rabi crop cultivated over 8000 ha in the sub-Himalayan plains of West Bengal, India.
Though rapeseed-mustard is the major oilseed of this region, the productivity is very poor (491 $\mathrm{kg} \mathrm{ha}^{-1}$ ) compared to the state average productivity $\left(889 \mathrm{~kg} \mathrm{ha}^{-1}\right)$. This declination in productivity might be due to use of sub-optimal dose of fertilizers and lack of use of sufficient amount of organic matter in the nutrient management practices and this is also to be a major reason for decline in fertilizer use efficiency (Bourguignon, 2005). Sometimes poor and uneven crop establishment is also responsible for lower seed yield of this oilseed crop. Maintaining a uniform crop stand is also a challenge in the eastern sub-Himalayan plains (Islam et al., 2013).

Recent advances in agriculture are focused on the reduction of the use of inorganic fertilizers, search for alternative ways to improve crop yield in sustainable agriculture. In spite of its efficiency in promoting crop yields chemical fertilizers have proved to be hazardous for soil health and well being of human and animal populations. So to maintain long-term soil health and crop productivity in intensive cropping system have underlined the need for integrated nutrient management practice comprising chemical fertilizers, organic manures, bio-fertilizers etc. (Hegde et al., ISSN : 0974-9411 (Print), 2231-5209 (Online) All Rights Reserved @ Applied and Natural Science Foundation www.ansfoundation.org 
1999). On the other hand pre-sowing seed priming not only homogenizes a seed lot, but this practice also gives a good crop stand to combat the adverse field condition. Seed priming also enhances metabolic activities and respiration rates by activating of enzymes involved in metabolism of seed reserves (Mauromicale and Cavallro, 1995), which gives a seed an earlier and increased germination, better and uniform field establishment. Improved emergence, dry matter accumulation as well as increased seed yield in rapeseed-mustard can be achieved through treating the seeds before sowing (Paul et al., 1999). Keeping fertility and seed-soaking factors in mind this field experiment was under taken to study the growth pattern, ability of nutrient uptake and ultimately the seed yield of the yellow sarson, the popular oilseed crop of the sub- Himalayan plains.

\section{MATERIALS AND METHODS}

The experiment was carried out during two consecutive years viz. rabi, 2007-08 and 2008-09 at Uttar Banga Krishi Viswavidyalaya, situated at the sub-Himalayan plains West Bengal, India, with different treatment combinations tested on yellow sarson (Brassica rapa var. yellow sarson). The experimental soil was slightly acidic in reaction $(\mathrm{pH}$ 6.14), sandy loam in texture having mineralizable $\mathrm{N}$ (216.38 $\left.\mathrm{kgha}^{-1}\right)$, available $\mathrm{P}_{2} \mathrm{O}_{5}$ (46.52 $\left.\mathrm{kgha}^{-1}\right)$, available $\mathrm{K}_{2} \mathrm{O}\left(147.45 \mathrm{kgha}^{-1}\right)$ and available $\mathrm{SO}_{4}^{-2}$ $\left(35.20 \mathrm{kgha}^{-1}\right)$. The experiment was laid out in factorial randomized block design with twenty four treatment combinations and replicated thrice. The treatments comprised of the different integrated nutrient management practices viz. 60:30:30 Kg N-P $\mathrm{O}_{5}-\mathrm{K}_{2} \mathrm{O}$ $\mathrm{ha}^{-1}$ as recommended dose; $100 \%$ recommended dose $+20 \mathrm{~kg} \mathrm{ha}^{-1}$ Sulphur; $75 \%$ recommended dose $+5 \mathrm{tha}^{-1}$ farm yard manure; $75 \%$ recommended dose $+5 \mathrm{t} \mathrm{ha}^{-1}$ vermicompost; $75 \%$ recommended dose $+5 \mathrm{t} \mathrm{ha}^{-1}$ farm yard manure $+5 \mathrm{~kg} \mathrm{ha}^{-1}$ Azotobacter; $75 \%$ recommended dose $+5 \mathrm{t} \mathrm{ha}^{-1}$ farm yard manure $+5 \mathrm{~kg} \mathrm{ha}^{-1}$ phosphate solubilizing bacteria; $75 \%$ recommended dose $+5 \mathrm{tha}^{-1}$ farm yard manure $+5 \mathrm{~kg} \mathrm{ha}^{-1}$ Azotobacter $+5 \mathrm{~kg} \mathrm{ha}^{-1}$ phosphate solubilizing bacteria and $75 \%$ recommended dose $+5 \mathrm{t} \mathrm{ha}^{-1}$ farm yard manure $+20 \mathrm{~kg} \mathrm{ha}^{-1}$ Sulphur. Seeds soaked with water and agro-chemicals (100ppm $\mathrm{Na}_{2} \mathrm{HPO}_{4}$ and 100 ppm $\mathrm{KH}_{2} \mathrm{PO}_{4}$ ) have also been used as the treatments. In treatment combinations under the study, the organic manure were applied along with chemical fertilizers and bio-fertilizers, based on blanket application in lieu of nutrient content as the nutrient content in organic manure varies widely with location, raw materials and production process. Use of secondary nutrient like $S$, has also been included in the treatment combination considering the higher requirement of $\mathrm{S}$ by yellow sarson. The variety chosen for the experiment was NC-1, popularly known as Jhumka. It takes about 95-100 days to mature, seed colour is yellow. Fertilizers were applied in the plots as per treatments just after laying out of the experiment. Nitrogen and potash were applied as basal and top dressing. Nitrogen was applied in two splits (half as basal and rest half as top dressing at 37 and 39 days after sowing during two years of experimentation), while three-fourth potassium was applied during final land preparation with one-fourth as top dressing at the same time of application of nitrogen. Entire phosphatic fertilizers were applied as basal. The source of $P$ was di-ammonium phosphate, while the same fertilizer and urea along with muriate of potash were served as the sources of $\mathrm{N}$ and $\mathrm{K}$ respectively. Sulphur was applied in the form of elemental sulphur just after the application of chemical fertilizers as per the treatment schedule and mixed thoroughly with soil. Boron was applied in each plot equally in the form of borax @ 10 $\mathrm{kg} \mathrm{ha}{ }^{-1}$. Well decomposed farm yard manure, vermicompost, Azotobacter and phosphate solubilizing bacteria were applied as per treatments and mixed thoroughly with the soil sixth and fifth days of application of chemical fertilizers and sulphur in the first and second year respectively. For the seed soaking treatments, solutions were prepared by dissolving $0.1 \mathrm{~g}$ of $\mathrm{Na}_{2} \mathrm{HPO}_{4}$ either or $\mathrm{KH}_{2} \mathrm{PO}_{4}$ in distilled water and volume was made up to $1000 \mathrm{ml}$. Keeping the seed rate of yellow sarson as $6.0 \mathrm{~kg} \mathrm{ha}^{-1}$, the seed rate for the each experimental plot sized 12 sq.m was calculated and that quantity of seeds were placed in different containers used for different plots and treatments accordingly. After that the seeds were soaked with water, $\mathrm{Na}_{2} \mathrm{HPO}_{4}$ and $\mathrm{KH}_{2} \mathrm{PO}_{4}$ as per the treatment schedule and allowed to absorb moisture up to $35 \%$ of their weight and kept in imbibed condition for $6 \mathrm{hrs}$ and the seeds were then spread out in a thin layer for drying under shade before sowing. The sowing was done on November 03 and October 31 in the first and second year of experimentation respectively. Seeds were sown in lines in both the years with the help of duck foot tyne by opening a shallow furrow at uniform depth $(2.5$ to $3.0 \mathrm{~cm})$, keeping the rows $30 \mathrm{~cm}$ apart. The seeds were covered immediately after sowing. For maintaining appropriate plant to plant distance, thinning was done. In both the years, thinning was performed once at 14 days after sowing. Light irrigation $(2-3 \mathrm{~cm})$ was given to the yellow sarson crop at 37 and 39 days after sowing in the first and second year respectively. Each experimental plot was divided in to two equal halves. One half was kept undisturbed for determining yield and remaining half was used for recording biometrical observations including destructive samples. Leaf area index (LAI) was obtained by using area-weight relationship where leaf areas of dried leaf samples were worked out (Kemp, 1960). Leaf area duration is a measure of the ability of the plant to produce leaf area on unit land area throughout its life. Leaf area duration was calculated by the following formula.

$\mathrm{LAD}=\frac{\mathrm{L}_{2}-\mathrm{L}_{1}}{\text { Loge } \mathrm{L}_{2}-\text { Loge } \mathrm{L}_{1}} \mathrm{\text {- }}$ 
Where, $L_{2}$ and $L_{1}$ are the final and initial leaf area indices at respective time.

Plant heights were measured with a meter scale from ground level to the tip of the main stem. No. of primary branches were recorded simply by counting method. To record dry matter accumulation the sampled plants were separated in to leaves, stem, root and reproductive parts, then the samples were oven dried at $65^{\circ} \mathrm{C}$ to $70^{\circ} \mathrm{C}$ till constant weight were obtained. Those weights were then converted in to weight $\mathrm{m}^{-2}$ taking into consideration the row spacing. The crop growth rate was measured using following formula.

Crop growth rate $=\frac{\mathrm{w}_{2}-\mathrm{w}_{1}}{\left.------\mathrm{g} \mathrm{m}^{-2} \mathrm{day}^{-1}\right)}$

Where, $\mathrm{w}_{1}$ and $\mathrm{w}_{2}$ were the initial and final dry weights of all the plant parts per unit area at times $t_{1}$ and $t_{2}$ respectively.

Stomatal conductance, transpiration rate and net photosynthesis rate (NPR) of yellow sarson were recorded at 45 days after sowing in both years by hand held portable photosynthesis system (model no. CI-340) on the third available leaf from the top between 12 noon to $1 \mathrm{pm}$. To measure average diameter, total root length of the yellow sarson plants, randomly selected representative ten plants from all the treatments were studied during maturity with Delta $\mathrm{T}$ Scan (splash cover) by lifting plants from each plot with the help of a spade without damaging the root system and the root dry weight plant $^{-1}$ was measured after oven drying the root samples at $65^{\circ} \mathrm{C}$ to $70^{\circ} \mathrm{C}$ till constant weights were recorded. The crop was harvested plot wise on February 16, 2008 for the first year of experiment and on February 15, 2009 for the second year of experiment. All the data have been recorded here as the pooled of the two years of experimentation. For estimating uptake of nutrients the plants were analyzed. Plant nitrogen content was estimated by digestion with concentrated $\mathrm{H}_{2} \mathrm{SO}_{4}$ and distillation process (Jackson, 1973), Plant phosphorus and potassium content was estimated by Tri-acid digestion process (Jackson, 1973) and the plant sulphur by Turbidimetry method as described by Chesnin and Yien(1951). The statistical analysis of data was done following the procedure for analyzing factorial randomized block design and by using statistical software MSTAT-C version 2.1(Michigan State University, USA). Significant differences between the treatments were compared with the critical difference at $\pm 5 \%$ probability by least significant difference.

\section{RESULTS AND DISCUSSION}

The results of the experiment indicated that the leaf area index (LAI) at the different growth stages, total leaf area duration, plant height and the number of primary branches plant ${ }^{-1}$ of yellow sarson were significantly influenced by the different nutrient management practices (Table 1). The highest value of leaf area index (4.00) was recorded at 60 days after sowing where the crop received $75 \%$ of the recommended dose along with farm yard manure, Azotobacter and P.S.B. This was in line of conformity with the findings of Mir (2003).This was also noticed that this nutrient management practice was helpful in maintaining higher values of LAI throughout the growing period, which ultimately reflected in to the integrated leaf area index over time i.e. total leaf area duration (128.17 days). Plant height also increased markedly due to combined application of $75 \%$ recommended dose farm yard manure + Azotobacter + P.S.B (139.97 $\mathrm{cm})$ over the $100 \%$ recommended dose $(116.48 \mathrm{~cm})$ recorded at the maturity stages. The number of primary branches plant ${ }^{-1}$ followed the same trend. Similar trend of results was also found in Indian mustard by Patel and Shelke (1998). Both the seed soaking agro-chemicals showed significantly greater impact over the water soaked seeds on LAI, leaf area duration, plant height and number of primary branches. Significant increase in LAI at 60 DAS (3.72), total leaf area duration (118.43 days), plant height $(133.21 \mathrm{~cm})$ and number of primary branches plant ${ }^{-1}$ (5.83) were recorded where the yellow sarson seeds were soaked with 100ppm $\mathrm{KH}_{2} \mathrm{PO}_{4}$ compared to water soaked seeds, but these values were statistically at par with the values where the seeds were soaked with 100 ppm $\mathrm{Na}_{2} \mathrm{HPO}_{4}$. Irrespective of treatments, the leaf area index increased steadily up to 60 days after sowing, and then it declined rapidly due to senescence of leaves as the crop progressed towards its maturity. The first pre-requisite for high yields of crop plants is a high production of total dry matter per unit area.

The amount of dry matter production depends on photosynthesis which in turn depends on large and efficient assimilating area, adequate supply of solar radiation and carbon di-oxide and favourable chemical conditions. An amount of photosynthates are used in respiration which is essential for maintenance and development. The total yield of dry matter is, therefore, the amount of dry matter produced less the photosynthates used for respiration. Finally, the amount of economic yield depends on the manner in which the net dry matter produced is distributed among the different parts of the plant. The results showed (Table 2) that dry matter production increased gradually and progressively till 90 days after sowing and thereafter at the harvesting stage a slight decrease in dry matter have been observed in all the treatments applied. Decrease in dry matter accumulation after 90 days after sowing was due to senescence of dried leaves and some of the other dried plant parts. Dry matter production at different growth stages varied significantly due to the different levels of nutrient management practices. High dry matter accumulation at the combined application of $75 \%$ of recommended dose of chemical fertilizer along with farm yard manure and both the bio-fertilizers (Azotobacter and P.S.B) was the 


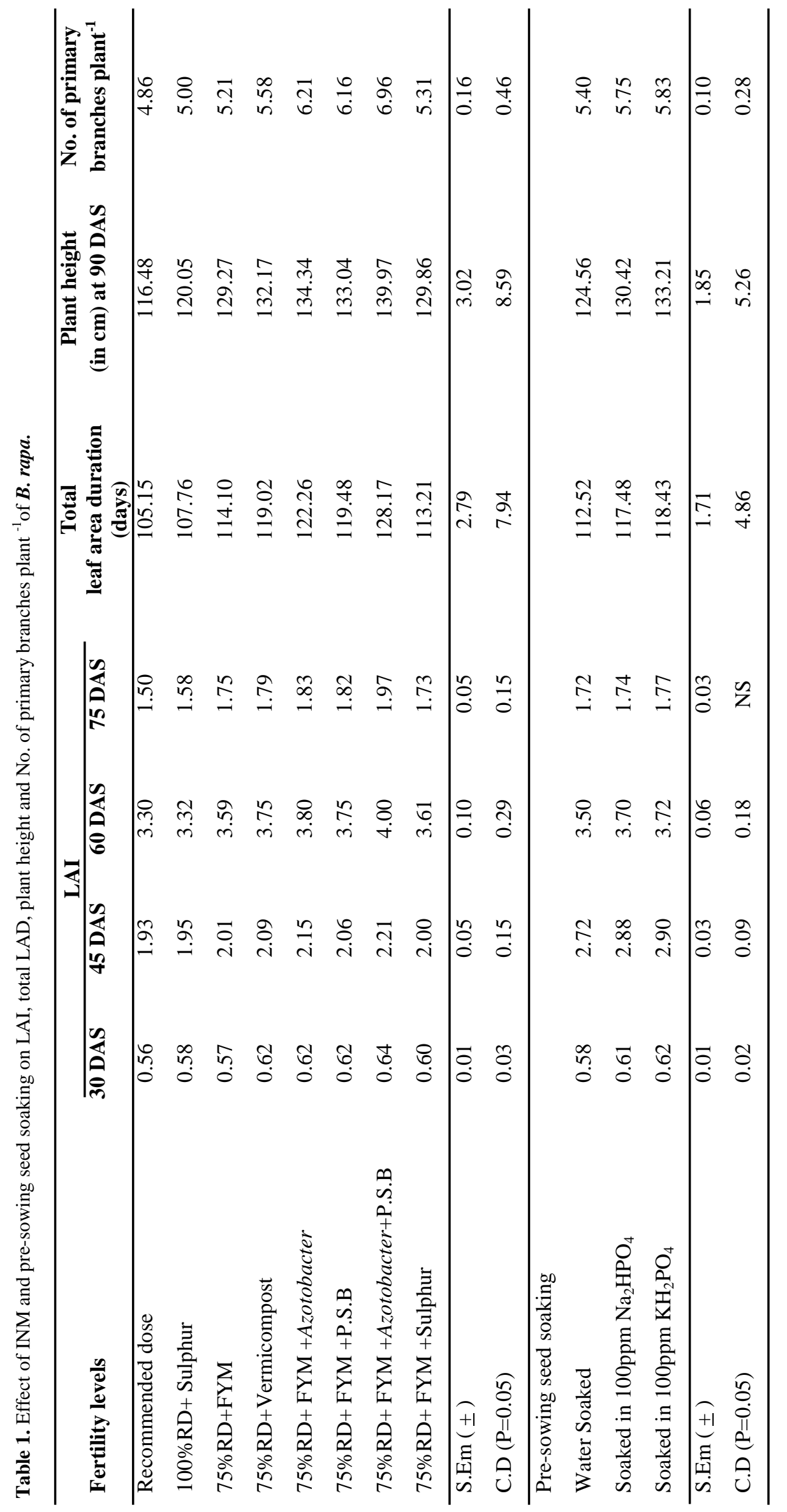


Saikat Mookherjee et al. / J. Appl. \& Nat. Sci. 6 (2): 416-425 (2014)

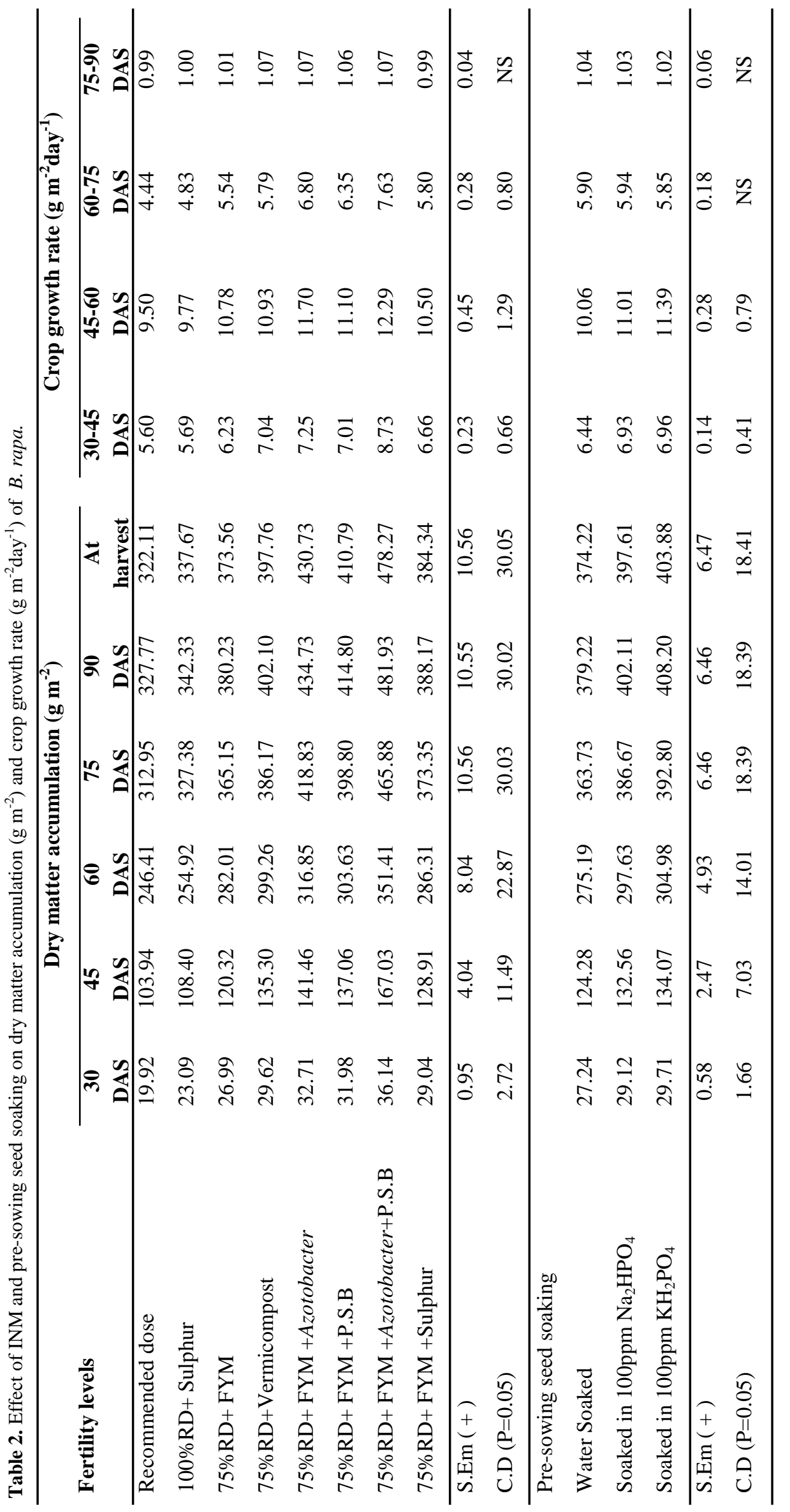




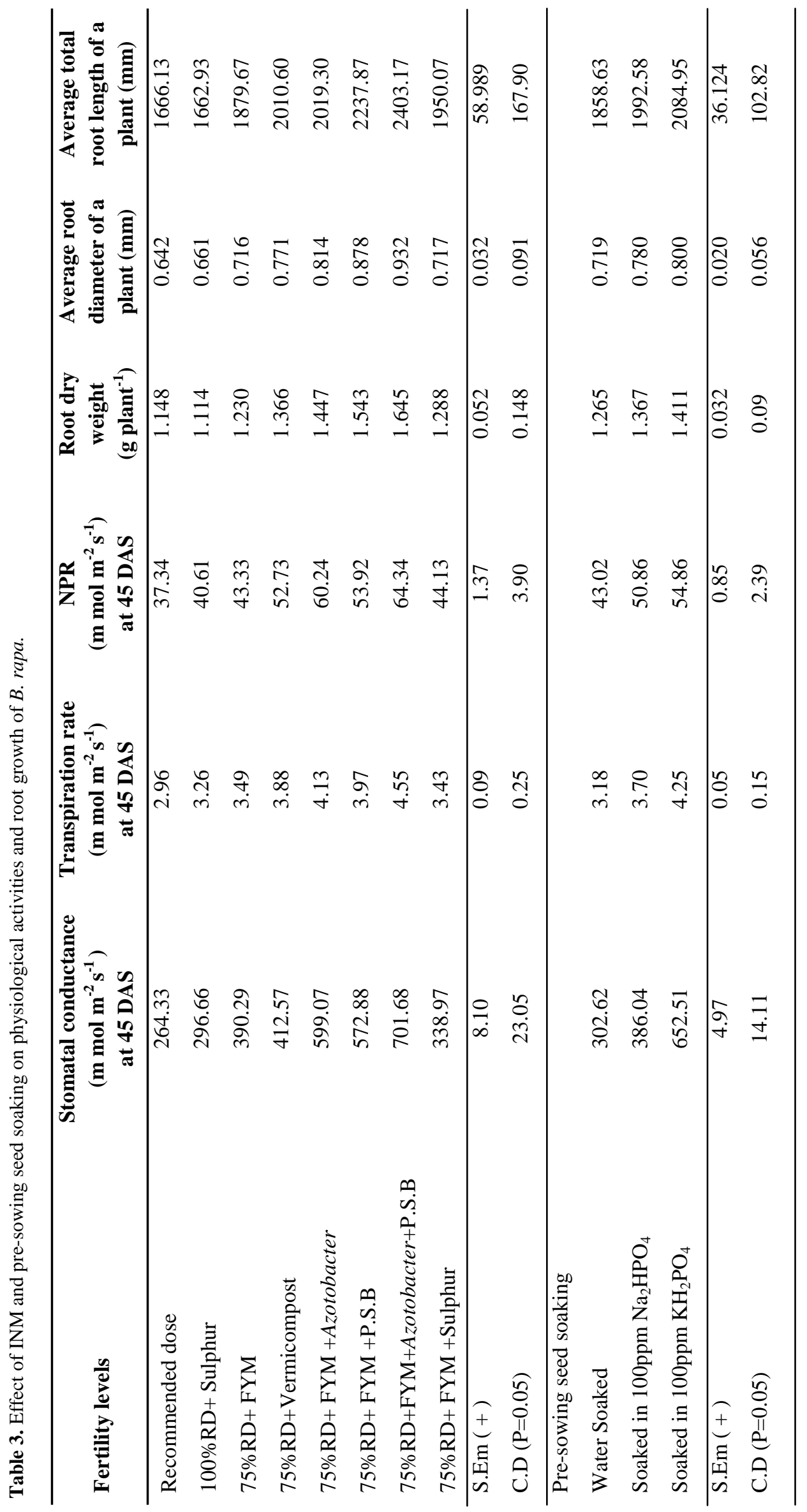


resultant effect of balanced crop nutrition and high leaf area indices acted over the growth period. A strong and positive relationship between LAI and dry matter yield helped this fertility treatment to show highest values at all the growth stages. The crop growth rate gives an insight not only on the performance of a particular genotype, but also on the impact of the superimposed agronomic practices on the crop at any particular stage of growth as well as on the final yield. It was observed that the crop growth rate increased gradually up to 60 days after sowing then it declined sharply as the crop progressed towards its maturity during both the years. In all the stages the highest values of crop growth rate were recorded in treatments receiving $75 \%$ of recommended dose, farm yard manure, Azotobacter and P.S.B. As per the data recorded at different growth stages, it has also been found that there is no significant effect of fertility levels on crop growth rate after 75 days after sowing of yellow sarson crop. The crop growth rate also has a strong and positive relation with LAI and dry matter accumulation which influenced the results on these growth variables. The results revealed that the beneficial effect of organic manures and bio-fertilizers along with $25 \%$ curtailment in chemical fertilizer in improving the crop growth rate of yellow sarson at the terai region of eastern India. The results also showed significant effect of seed soaking with $\mathrm{KH}_{2} \mathrm{PO}_{4}$ and $\mathrm{Na}_{2} \mathrm{HPO}_{4}$ in comparison to seeds soaked with water. The highest values of dry matter accumulation at maturity $\left(403.88 \mathrm{~g} \mathrm{~m}^{-2}\right)$ and of crop growth rate at 45-60 days after sowing (11.39 $\mathrm{g} \mathrm{m}^{-2}$ day $\left.^{-1}\right)$ were recorded with $100 \mathrm{ppm} \mathrm{KH}_{2} \mathrm{PO}_{4}$ soaked seed but no significant variation was found amongst the seed soaking treatments during 60-75 and 75-90 days after sowing.

Transpiration is necessary evil for any crop. It is a vital and unavoidable phenomenon of plant. As long as there is need of ingress and regress of carbon-dioxide, during metabolic process like photosynthesis and respiration, living cells have to be exposed, the transpiration will be unavoidable. Transpiration creates a suction force and helps in the ascent of sap, it affects the absorption of water and mineral by roots; it is supposed to play a necessary role in the translocation of food from one portion of the plant to the others, it brings about the opening and closing of stomata which indirectly influence the process of photosynthesis and respiration. $75 \%$ of recommended dose of chemical fertilizers along with farm yard manure, Azotobacter and P.S.B showed (Table 3) significantly higher stomatal conductance $\left(701.68 \mathrm{mmolm}^{-2} \mathrm{~s}^{-1}\right)$ and transpiration rate $\left(4.55 \mathrm{mmolm}^{-2} \mathrm{~s}^{-1}\right)$ over other nutrient management practices in yellow sarson at 45 days after sowing. As the net photosynthesis rate is the copulation of many of these physiological factors, same trend in result is obvious in net photosynthesis rate with same integrated nutrient management practice at the same stage of the crop $\left(64.34 \mathrm{mmolm}^{-2} \mathrm{~s}^{-1}\right)$. Through better root proliferation this nutrient management practice also showed significant increase in root dry weight $\operatorname{plant}^{-1}\left(1.645 \mathrm{~g} \mathrm{plant}^{-1}\right)$, average root diameter of a plant $(0.932 \mathrm{~mm})$ and total root length of a plant $(2403.17 \mathrm{~cm})$ over the $100 \%$ recommended dose of chemical fertilizers applied but these results are statistically at par with the results obtained in nutrient management practice consisting $75 \%$ recommended dose + farm yard manure+ P.S.B in yellow sarson plants. Pre-sowing seed soaking with $\mathrm{KH}_{2} \mathrm{PO}_{4}$ showed significantly higher stomatal conductance, transpiration rate as well as net photosynthesis rate of yellow sarson over the seed soaking treatment with $\mathrm{Na}_{2} \mathrm{HPO}_{4}$ and water. Significantly higher values of root dry weight plant $^{-1}\left(1.411 \mathrm{~g} \mathrm{plant}^{-1}\right)$, average root diameter of a plant $(0.800 \mathrm{~mm})$ and total root length of a plant $(2084.95 \mathrm{~cm})$ were obtained with pre-sowing seed soaking with $100 \mathrm{ppm} \mathrm{KH}_{2} \mathrm{PO}_{4}$ in comparison with water soaked seeds, but these results were statistically at par with $100 \mathrm{ppm} \mathrm{Na}_{2} \mathrm{HPO}_{4}$ soaked seeds.

With the developed root system, higher uptake of nutrients reflected in to the seed yield of yellow sarson due to integrated nutrient management practice and soaking of seeds before sowing (Table 4). It was also revealed that the combination of inorganic sources and organic sources with or without bio-fertilizers are always beneficial for uptake of nutrients to the yellow sarson crop over the sole application of chemical fertilizers. A significant difference in nitrogen uptake has been observed with Azotobacter (75\% of the recommended dose + farm yard manure + Azotobacter + P.S.B) and without Azotobacter (75\% of the recommended dose + farm yard manure+ P.S.B) when the other components of the treatments remained the same. Significantly higher nitrogen, phosphate, potassium and sulphur uptake were observed where the crop received farm yard manure, Azotobacter and PSB along with inorganic fertilizer applied after $25 \%$ curtailment of recommended dose comparison to sole application of chemical fertilizers. Higher nutrient uptake by the yellow sarson crop in this integrated nutrient management practice was mainly due to better growth and higher dry matter yield of the crop apart from some contribution by increased nutrient content in the plant parts. Poor growth and low dry matter productivity were primarily responsible for the lowest nutrient uptake by the crop receiving only the chemical source of the nutrients. This might be explained as the inefficient utilization of nutrient by the crop in the absence of organic matter and bio-fertilizers particularly in the terai soil of West Bengal. This result indicated the need of an integration of different sources on plant nutrients for greater nutrient uptake by yellow sarson crop. Chand and Ram (2007) also observed the significant and positive correlation of coefficient between Azotobacter and nitrogen uptake in mustard when Azotobacter was applied with FYM. Improved growth of the crop together with high dry matter yield 


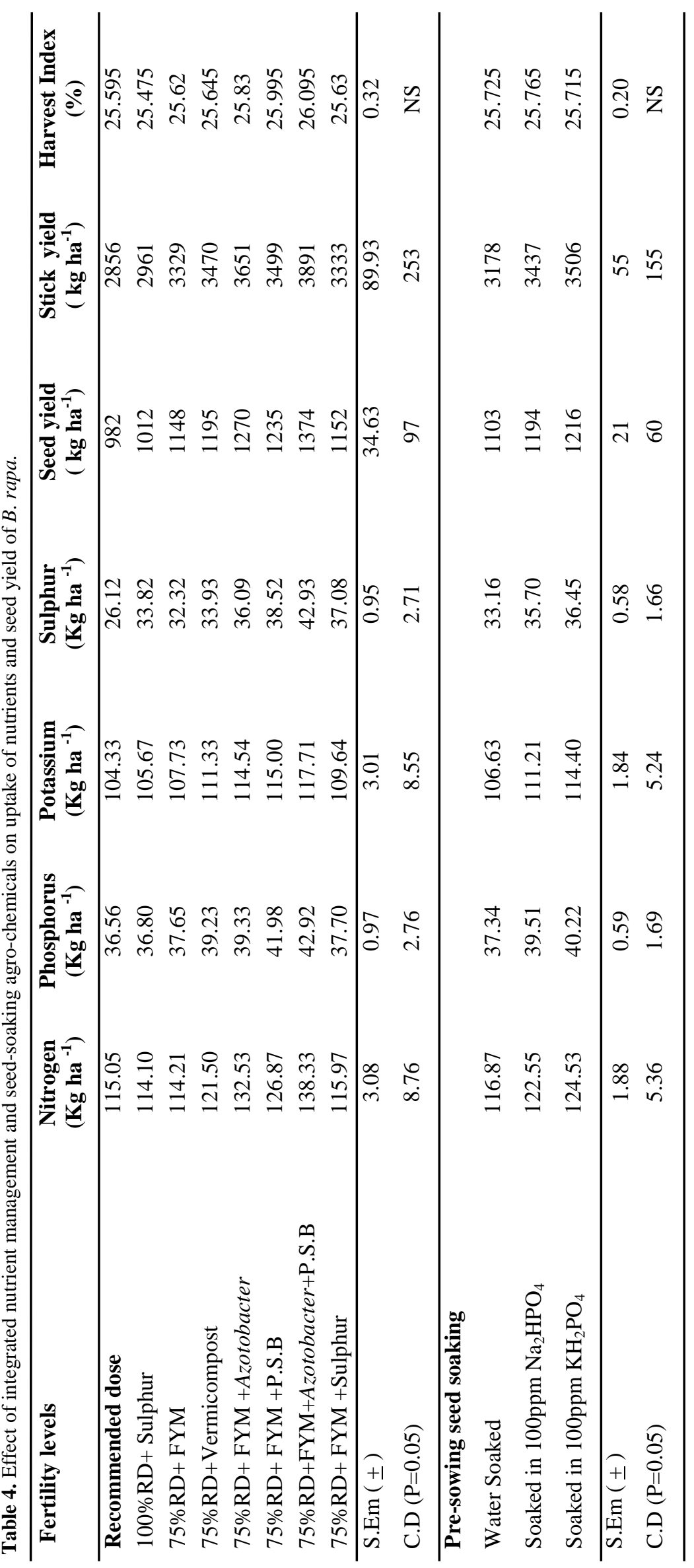


through extensive root system with better proliferation were mainly responsible for higher uptake of nutrients and better seed yield. Highest seed (1374 $\left.\mathrm{kg} \mathrm{ha}^{-1}\right)$ and stick yield (3891 $\mathrm{kg} \mathrm{ha}^{-1}$ ) were obtained with the application of $75 \%$ of the recommended dose of chemical fertilizers + farm yard manure + Azotobacter + PSB form the integrated nutrient management schedule. An increment of $39 \%$ in seed yield has been observed with this nutrient management practice over sole application of recommended dose of chemical fertilizers. Pre-sowing seed soaking also had a greater impact in uptake of nutrient and its conversion in to the biomass yield. Though pre-sowing seed soaking with 100ppm $\mathrm{KH}_{2} \mathrm{PO}_{4}$ showed highest seed $\left(1216 \mathrm{~kg} \mathrm{ha}^{-1}\right)$ and stick yield (3506 $\mathrm{ka} \mathrm{ha}^{-1}$ ), but these were statistically at par with 100ppm $\mathrm{Na}_{2} \mathrm{HPO}_{4}$ soaked seeds. Seeds soaked with water before sowing reflected $9 \%$ lesser seed yield compared to $\mathrm{KH}_{2} \mathrm{PO}_{4}$ soaked seeds. No significant variations were found in harvest index of yellow sarson with both integrated nutrient management practices and pre-sowing seed soaking treatments.

It is reported that that the important non-symbiotic nitrogen fixing bacteria Azotobacter and phosphate solubilizing bacteria can benefit rapeseed-mustard (Anonymous, 2005). Azotobacter and phosphate solubilizing bacteria (P.S.B) beside fixing ambient nitrogen to the soil and solubilize phosphates in the soil, can benefit rapeseed-mustard by producing growth hormones, viz., IAA, gibberellins and making the soil nutrient in available form (Bais et al., 2006 and Bisht et al., 2009). These hormones might have played a vital role to stimulate root growth and development as well as better utilization of light interception which helped in greater uptake of nutrients by efficient photosynthetic activities. The maximum root length at harvest in rapeseed was also observed by Mitra et al. (2008) with the fertility levels in which both organic and inorganic sources were applied. Side by side farm yard manure is considered as a good substrate for the bio-fertilizers. With a buffering tendency, farm yard manure also increases fertilizer use efficiency, supplies micronutrients and makes the nutrients in the soil more available to plants even in slightly acidic soil. Thus combined application of $75 \%$ recommended dose, farm yard manure, Azotobacter and P.S.B might helped the plants in absorption of nutrients from soil solution by expanding the energy in available form which ultimately helped the plant to develop a good crop canopy with good number of primary branches, root system and leaf size. These factors ultimately triggered the seed yield of yellow sarson crop. Chatterjee (2013) also found the beneficial effects of farm yard manure, Azotobacter and phosphate solubilizing bacteria on tomato physiological traits at foot-hills of eastern Himalaya. Considering other factor, better preservation of cellular substances with sequential changes in the viscosity and elasticity of protoplasm, lower water deficit, increase in water balance and extensive root system of plants are the physiological basis for pre-sowing seed soaking (Bharathi et al., 2004). Water absorption of seeds by greater membrane permeability and translocation of sugars from seed to young growing points is the another advantage of pre-sowing seed soaking (Balasubramaniyan and Palaniappan, 2002). Thus pre-sowing seed soaking has a greater role in early emergence of seedlings with proper root and shoot growth, which helps a plant in uptake of nutrients accumulated at the root zone at different growth stages. High seedling vigour, faster emergence and increased DNA at the growing points might be helpful for the plants towards uptake and higher translocation of the nutrients efficiently. Enhanced physiological processes from very beginning of the growth stages recorded increased plant height thereby. ATP is the biological energy needed for every biosynthetic pathways as well as biological work. During early crop establishment, the embryo of a seed not only acts as the source for enzyme substrate but also co-factors for the synthesis of ATP. So the pre-sowing seed soaking with phosphorus containing salts might have a contribution in early active absorption, translocation of plant nutrients accumulated in available form at the soil solution near the root zone of the plants and better photosynthetic activities with light interception. Absorption of nutrients from soil solution containing low concentration of nutrients compared to plant sap by expanding energy which largely depends on growth and development of roots which determines the leaf size, number of leaves and leaf area index. Pre-sowing seed soaking with chemicals has a role in early emergence, vigorous seedlings along with steady root growth. Seeds soaked with $\mathrm{KH}_{2} \mathrm{PO}_{4}$ and $\mathrm{Na}_{2} \mathrm{HPO}_{4}$ might have a great influence on better uptake and translocation of the plant nutrients and ultimately increased seed yield of yellow sarson. This was in conformity with the results found by Paul et al. (1999). Similar results were also found by Mondal et al. (2004) in a field study to evaluate the effect of pre-sowing seed treatment with water and different agro-chemicals in B. juncea. One-fourth curtailment in the recommended dose of chemical fertilizers and inclusion of organics and bio-fertilizers was proved to be superior over the use of only chemicals in terms of growth, nutrient uptake and productivity of yellow sarson. One another remarkable factor needed to be addressed that the use of agro-chemicals for soaking of seeds before sowing which also ultimately gave yellow sarson a uniform stand and productivity.

\section{Conclusion}

Integrated nutrient management and pre-sowing seed soaking of yellow sarson showed distinct effect on yellow sarson growth attributes, nutrient uptake and seed yield, a recommendation may come out in 
combination of both the factors. In this study, $75 \%$ recommended dose of chemical fertilizer, farm yard manure, Azotobacter, phosphate solubilizing bacteria and sowing of seeds after soaking of seeds in 100ppm $\mathrm{KH}_{2} \mathrm{PO}_{4}$ came out as the best treatment among the treatment combinations used. This package can be beneficial for the rapeseed mustard growers at the eastern part of Indian Sub-Himalayan terai plains.

\section{REFERENCES}

Anonymous (2005). Integrated nutrient management for oilseed crops, Directorate of Oilseeds Research (ICAR), Hyderabad (Ed. Hegde,D.M.).

Bais, H.P., Weir, T.L., Perry, L.G., Gilroy, S. and Vivanco, J.M. (2006). The role of root exudates in rhizosphere interactions with plants and organisms. Annual Review of Plant Biology, 57:233-266.

Balasubramaniyan, P. and Palaniappan, S.P. (2002). Dryland agriculture and watershed management. Principles and Practices of Agronomy. Agrobios (India), Jodhpur, Rajasthan. pp.388-389.

Bharathi, A., Natesan, P., Parameshwari, K. and Raja, K. (2004). Seed quality enhancement techniques. Compendium on Seed Science and Technology, Tamil Nadu Agricultural University, pp. 60-80.

Bisht, R., Chaturvedi, S., Srivastava, R., Sharma, A.K. and Johri, B.N. (2009). Effect of arbuscular mycorrhizal fungi, Psudomonas fluoresccens and Rhizobium leguminosarum on the growth and nutrient status of Dalbergia sissoo Roxb. Tropical Ecology, 50(2):231-242.

Bourguignon, C. (2005). Regeneration the soil. Other India Press, Goa, India, pp.62.

Chand, S. and Ram, D. (2007). Effect of Integrated nutrient management on yield and nutrient use efficiency in Mustard. Indian Journal of Fertilizers, 3(5):51-54.

Chatterjee, R. (2013). Physiological attributes of tomato (Lycopersicon esculentum Mill.) influenced by different sources of nutrients at foothill of eastern Himalayan region. Journal of Applied and Natural Sciences, 5 (2):282-287.

Chesnin, L. and Yien, C.H. (1951). Turbidimetric determination of available sulphate. Soil Science Society America Proceedings, 15:149-151.

Colton, B. and Potter, T. (1999). Canola in Australia:The
First thirty years. P.A Salisbury, T. Potter, G. McDonald, A.G. Green, eds. 1-4.

Hegde, D.M., Dwivedi, B.S. and Sudhakarababu, S.N. (1999). Biofertilizers for cereals production in India - a review. Indian Journal of Agricultural Sciences, 69 (2):73-83.

Islam, M., Nath, L.K. and Samajdar,T. (2013). Cultivation of rapeseed and mustard. Krishi Vigyan Kendra, Tura. ICAR RC for NEH region, Kiran.nic.in/Farmer's corner/pamphlets.

Jackson, M.L. (1973). Soil chemical analysis, Prentice Hall of India Pvt. Ltd., New Delhi. Pp. 45-226.

Kemp, C.D. (1960). Methods of estimation of the leaf area of grasses from linear measurement. Annual Boval New Series, 2:96.

Mauromicale, G. and Cavallro, V. (1995). Effect of seed osmo priming on germination of tomato at different water potential. Journal of Seed Science and Technology, 23(2):107-126.

Mir, A.H., Hayat, S. and Ahmed, I. (2003). Performance of bio-fertilizer inoculation to Indian mustard. Brassica, 5 (3/4): 58-63.

Mitra, B., Mandal, B.K. and Hansda, S.K. (2008). Effect of paddy straw mulching and varying levels of fertility on root characteristics of rapeseed-greengram-rice crop sequence under rainfed condition. Crop Research, 36 (1,2 and 3):101-104

Mondal, S.S., Acharya, D., Sarkar, S. and Ghosh, A. (2004). Effect of pre-sowing seed treatment on growth, yield, quality and nutrient uptake on Indian mustard (Brassica juncea) under rain-fed condition. Indian Journal of Agronomy, 49(4): 262-263.

Patel, J.R. and Shelke, V.B. (1998). Effect of farm yard manure, phosphorus and sulphur on growth, yield and quality of Indian mustard (Brassica juncea). Indian Journal of Agronomy, 43(4): 713-717.

Paul, S.R., Sarma, N.N. and Sarma, D. (1999). Effect of pre-sowing seed treatments on toria (Brassica napus) and Indian mustard (Brassica juncea) under rain fed condition. Indian Journal of Agronomy, 44(2): 392-395.

Shekhawat, K., Rathore, S.S., Premi, O.P., Kandpal, B. K. and Chauhan, J.S. (2012). Advances in Agronomic Management of Indian Mustard (Brassica juncea L.). Czernj.Cosson): An Overview. International Journal of Agronomy, 2012:1-14. 